\title{
Studi Kapasitas Angkut dan Gerusan Lokal pada Penampang Sungai Brantas Akibat Pilar Jembatan Tol Mojokerto-Kertosono
}

\author{
Aisyah Amelia, Umboro Lasminto dan Bambang Sarwono \\ Departemen Teknik Sipil, Fakultas Teknik Sipil dan Perencanaan, Institut Teknologi Sepuluh Nopember (ITS) \\ e-mail:bambang_s@ce.its.ac.id
}

\begin{abstract}
Abstrak-Jalan Tol Mojokerto-Kertosono melintasi sungai Brantas di Kecamatan Gedeg, Mojokerto, untuk itu dibutuhkan jembatan sepanjang 299 m. Konstruksi jembatan tersebut berpotensi mengakibatkan terjadinya gerusan lokal pada dasar sungai maupun perubahan morfologi sungai. Oleh sebab itu perlu dilakukan studi kapasitas angkut dan gerusan lokal pada penampang sungai akibat pilar jembatan. Pada tugas akhir ini, dilakukan perhitungan debit rencana dengan metode Gumbel. Dalam analisa gerusan lokal digunakan modul Users Manual dan Reference Manual pada program Hec-Ras 5.0.3 untuk memprediksi kedalaman gerusan. Sedangkan analisa angkutan sedimen dihitung dengan permodelan sedimen pada program Hec-Ras 5.0.3. Hasil studi ini menghasilkan debit banjir rencana di sungai Brantas untuk 2 tahun, 5 tahun, 10 tahun, 25 tahun, 50 tahun, dan 100 tahun secara berturut-turut adalah $1.213,58 \mathrm{~m}^{3} / \mathrm{dt}, 1.444,48 \mathrm{~m}^{3} / \mathrm{dt}$, $1.597,36 \mathrm{~m}^{3} / \mathrm{dt}, 1.790,53 \mathrm{~m}^{3} / \mathrm{dt}, 1.933,83 \mathrm{~m}^{3} / \mathrm{dt}, 2.076,07 \mathrm{~m}^{3} / \mathrm{dt}$. Akibat dari contraction scour atau penyempitan sungai sebelum dibangun jembatan, pada debit 100 tahun terjadi gerusan sedalam $0,47 \mathrm{~m}$ di bagian kanan penampang sungai. Sedangkan setelah dibangun jembatan, diperkirakan gerusan akibat contraction scour dan pilar menjadi $7,4 \mathrm{~m}$, kedalaman ini mendekati hitungan analitis sebesar 8,07 m. Angkutan sedimen sebelum ada jembatan adalah $386.551 \mathrm{~m}^{3}$ dan penurunan dasar sungai rata-rata sebesar $1,03 \mathrm{~m}$. Sedangkan setelah ada jembatan, volume angkutan sedimen kumulatif yang terangkut adalah $569.775 \mathrm{~m}^{3}$ dengan penurunan dasar saluran rata-rata sebesar $1,51 \mathrm{~m}$.
\end{abstract}

Kata Kunci-Angkutan sedimen, Gerusan lokal, Morfologi, Sungai Brantas

\section{PENDAHULUAN}

$\mathrm{P}$ ERKEMBANGAN ekonomi dan teknologi mengalami kemajuan yang sangat pesat, hal ini menyebabkan adanya tuntutan-tuntutan untuk mempercepat pemenuhan infrastruktur sebagai penunjang kegiatan manusia, salah satunya jembatan. Jembatan merupakan prasarana transportasi yang berfungsi untuk memperlancar perpindahan barang dan manusia dari satu tempat ke tempat lainnya. Jembatan menghubungkan daerah-daerah yang terpisah karena adanya rintangan, seperti selat, sungai, atau jalan raya. Tol Mojokerto-Kertosono merupakan bagian dari proyek Trans Java Tollway System yang dimulai dari barat pulau Jawa tepatnya di Merak, Jawa Barat hingga Ketapang, Jawa Timur. Di Kecamatan Gedeg, Mojokerto, alinemen jalan tol ini melintang di atas Sungai Brantas sepanjang 299 $\mathrm{m}$.

Adanya penghalang seperti bangunan bawah jembatan dapat menyebabkan perubahan pada morfologi sungai berupa agradasi atau degradasi sedimen. Jika terjadi agradasi, dasar sungai akan mengalami pendangkalan dan tinggi bebas antara muka air sungai dengan bagian bawah jembatan juga berkurang. Jika terjadi degradasi, maka erosi dasar sungai akan mengakibatkan sungai semakin dalam, erosi tebing yang mengakibatkan sungai semakin lebar, sehingga menyebabkan terjadinya deposisi meander sungai. Selain itu, perubahan pola aliran yang disebabkan oleh adanya pilar dan abutment juga dapat mengakibatkan keseimbangan material dasar sungai terganggu. Sedimen yang terus-menerus mengendap dapat menyebabkan banjir karena kapasitas tampungan sungai yang berkurang, sedangkan sedimen yang terus-menerus terkisis akibat bertambahnya kecepatan aliran akan membuat struktur jembatan yang berada di atasnya menjadi tidak stabil.

Oleh karena itu, dibutuhkan analisa sedimen terhadap morfologi sungai dan analisa scouring pada penampang jembatan terhadap aliran sungai untuk mengetahui seberapa besar pengaruh yang terjadi akibat adanya jembatan.

\section{METODOLOGI PENELITIAN}




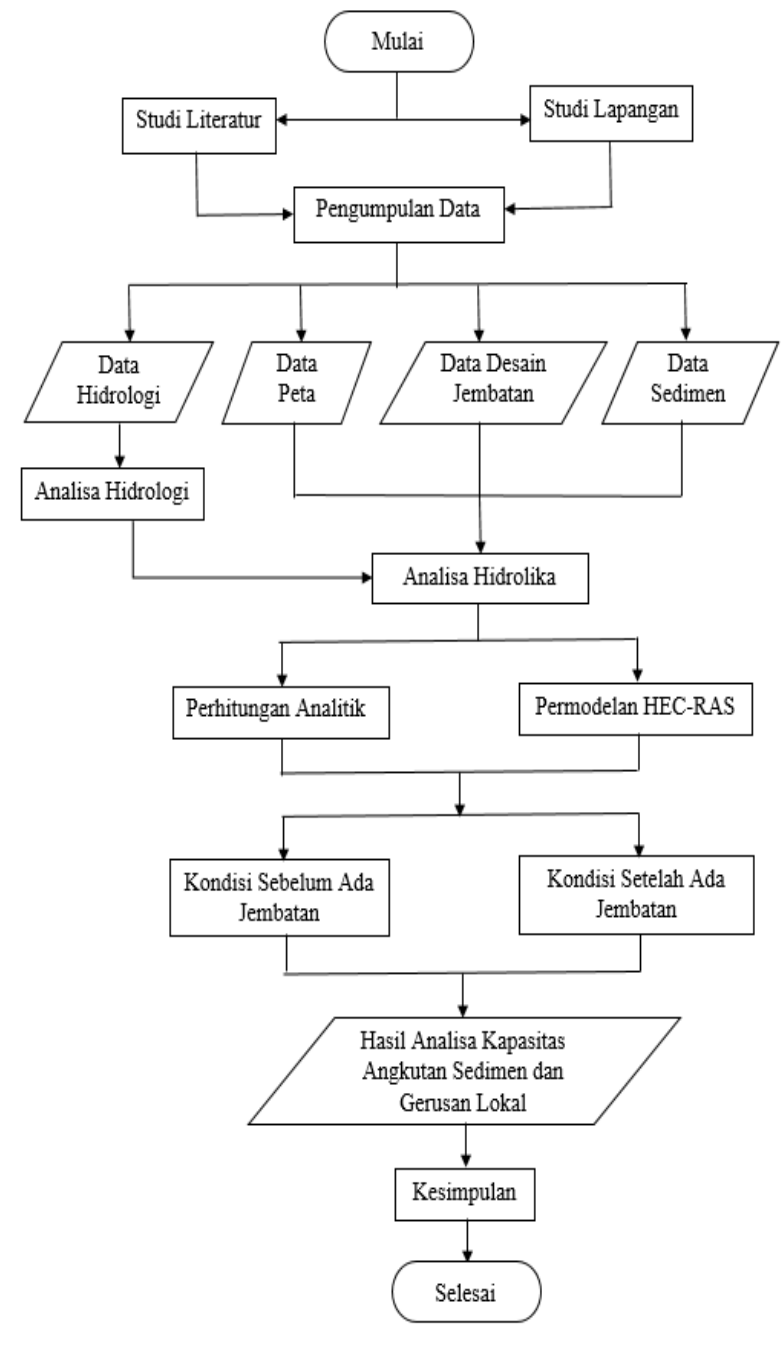

Gambar 1. Bagan Alir Penelitian.

\section{PEMBAHASAN}

\section{A. Analisa Hidrologi}

Analisa hidrologi yang dilakukan adalah perhitungan debit periode ulang yang melintasi ruas sungai pada lokasi studi. Debit periode ulang adalah debit yang terjadi satu kali di mana besarnya akan disamai atau dilampaui dalam periode tersebut.

Dalam tugas akhir ini debit periode ulang yang digunakan adalah 2 tahun, 5 tahun, 10 tahun, 25 tahun, 50 tahun, dan 100 tahun. Data yang digunakan adalah data debit harian yang tercatat dari pos pengamatan di Menturus dari Januari 1999 sampai dengan Januari 2011.

Dalam perhitungan debit periode ulang ini metode yang digunakan adalah metode Gumbel. Adapun langkah-langkah perhitungan adalah sebagai berikut:

1. Menghitung besar debit maksimum di setiap tahun.

2. Menghitung debit rata-rata maksimum.

3. Menghitung standar deviasi.

4. Menghitung konstanta $\alpha$ dan $u$.

5. Menghitung faktor reduksi Gumbel $\left(\mathrm{Y}_{\mathrm{T}}\right)$.

6. Menghitung debit periode ulang.

Berikut ini adalah salah satu contoh perhitungan debit periode ulang 2 tahun.
Tabel 1.

Data Debit Maksimum

\begin{tabular}{cccc}
\hline \hline Tahun & $\mathrm{X}$ & $\mathrm{X}-\mu$ & $(\mathrm{X}-\mu)^{2}$ \\
\hline 1999 & 1.120 & $-136,5$ & $18.632,25$ \\
2000 & 1.019 & $-237,5$ & $56.406,25$ \\
2001 & 1.170 & $-86,5$ & $7.482,25$ \\
2002 & 1.304 & 47,5 & $2.256,25$ \\
2003 & 955 & $-301,5$ & $90.902,25$ \\
2004 & 1.600 & 343,5 & $117.992,3$ \\
2005 & 949 & $-307,5$ & $945.56,25$ \\
2006 & 1.219 & $-37,5$ & $1.406,25$ \\
2007 & 1.707 & 450,5 & $202.950,3$ \\
2008 & 1.329 & 72,5 & $5.256,25$ \\
2009 & 1.224 & $-32,5$ & $1.056,25$ \\
2010 & 1.482 & 225,5 & $50.850,25$ \\
2011 & 828 & $-428,5$ & $183.612,3$ \\
\hline Jumlah & & & 649.747 \\
\hline$\mu$ & $1.256,5$ & & \\
\hline \hline
\end{tabular}

Sumber: Hasil Perhitungan

Ket: $\mu=$ nilai rata-rata

$s=\sqrt{\frac{\sum(X-\mu)^{2}}{n-1}}$

$$
=\sqrt{\frac{649747}{13-1}}=261,28
$$

$\alpha=\frac{\sqrt{6} \mathrm{~s}}{\pi}=203,72$

$\mathrm{u}=\mu+0,5772 \alpha=1.138,91$

$\mathrm{Y}_{\mathrm{T}}=-\ln \left[\ln \frac{\mathrm{T}}{\mathrm{T}-1}\right]=-\ln \left[\ln \frac{2}{2-1}\right]=0,37$

Sehingga, besarnya debit periode ulang 2 tahun adalah: $\mathrm{X}_{\mathrm{T}}=\mathrm{u}+\mathrm{Y}_{\mathrm{T}} \alpha=1.138,91+0,3665 \times 203,7227=$ $1.213,58 \mathrm{~m}^{3} / \mathrm{dt}$

Untuk perhitungan debit periode ulang lainnya sama seperti di atas dan hasilnya dapat dilihat pada Tabel 2.

Tabel 2.

Hasil Perhitungan Debit Rencana Periode Ulang

\begin{tabular}{ccc}
\hline \hline Periode Ulang & Yt & $\mathrm{Xt}\left(\mathrm{m}^{3} / \mathrm{dt}\right)$ \\
\hline 2 tahun & 0,367 & $1.213,58$ \\
5 tahun & 1,499 & $1.444,48$ \\
10 tahun & 2,250 & $1.597,36$ \\
25 tahun & 3,198 & $1.790,53$ \\
50 tahun & 3,902 & $1.933,83$ \\
100 tahun & 4,600 & $2.076,07$ \\
\hline \hline
\end{tabular}

Sumber: Hasil Perhitungan

\section{B. Analisa Hidrolika}

Analisa hidrolika pada tugas akhir ini dilakukan dengan menggunakan program bantu Hec-Ras 5.0.3. Jenis simulasi pada program ini ada dua, yaitu steady dan unsteady flow. Steady flow adalah aliran di mana ada kemungkinan perbedaan sifat-sifat aliran di setiap titik, tetapi tidak berubah terhadap waktu. Sedangkan unsteady flow adalah aliran di mana sifat aliran tidak tetap dan bergantung terhadap waktu.

C. Analisa Gerusan di Sekitar Pilar

1. Permodelan Gerusan pada Hec-Ras

Permodelan gerusan pada program Hec-Ras dilakukan dengan memilih menu Hydraulic Design Function pada 
tampilan utama dan memilih Bridge Scour pada Type. Pada analisa ini jenis scouring yang dapat diketahui, yaitu contraction scour, gerusan akibat pilar dan abutmen [1].

2. Permodelan Kondisi Sebelum Ada Jembatan

Permodelan kondisi sebelum ada jembatan dimaksudkan untuk mengetahui gerusan yang terjadi akibat penyempitan sungai. Pada kondisi ini pilar dihilangkan, sehingga pada penampang hanya terlihat deck jembatan saja. Beberapa data akan terisi secara otomatis, untuk contraction data yang dibutuhkan adalah ukuran sedimen d50, dan koefisien K1 yang bisa dihitung otomatis oleh program.

Berikut Gambar 2, Gambar 3, Gambar 4, Gambar 5, Gambar 6, dan Gambar 7 adalah hasil simulasi contraction scour pada program Hec-Ras 5.0.3:

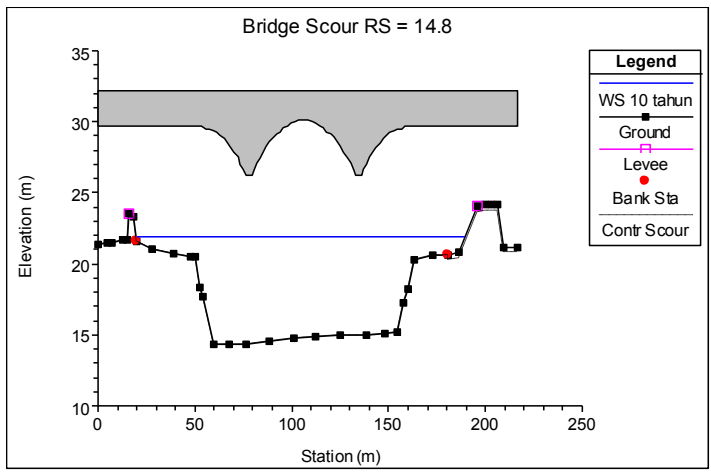

Gambar 4. Contraction Scour Yang Terjadi dengan Debit Rencana 10 Tahun

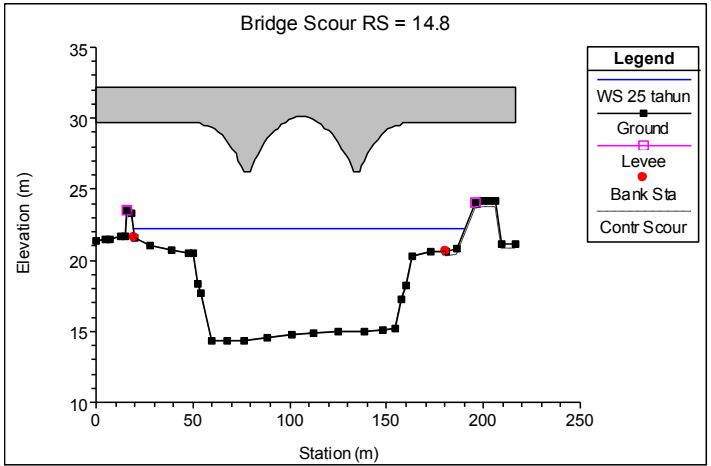

Gambar 5. Contraction Scour Yang Terjadi dengan Debit Rencana 25 Tahun

Hasil analisa kedalaman contraction scour disajikan dalam Tabel 3 di bawah ini.

Tabel 3.

Kedalaman Contraction Scouring terhadap Debit Periode Ulang pada Permodelan Hec-Ras

\begin{tabular}{ccccc}
\hline \hline \multirow{2}{*}{ Periode Ulang } & \multirow{2}{*}{ Debit $\left(\mathrm{m}^{3} / \mathrm{dt}\right)$} & \multicolumn{3}{c}{ Contraction Scour } \\
\cline { 3 - 5 } & & Left $(\mathrm{m})$ & Channel $(\mathrm{m})$ & Right $(\mathrm{m})$ \\
\hline 2 tahun & $1.213,58$ & - & 0 & 0,11 \\
5 tahun & $1.444,48$ & - & 0 & 0,38 \\
10 tahun & $1.597,36$ & 0 & 0 & 0,37 \\
\hline
\end{tabular}

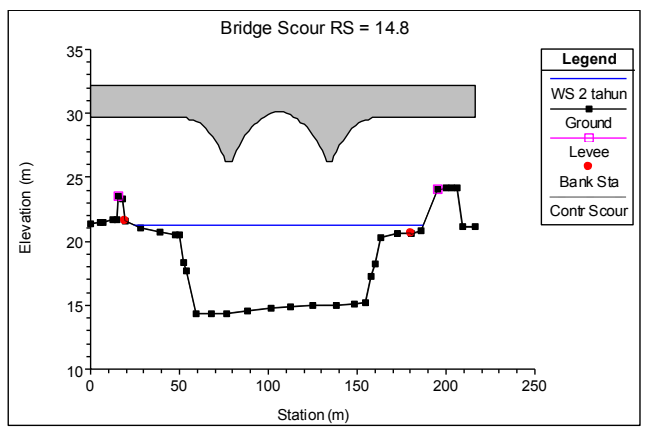

Gambar 2. Contraction Scour Yang Terjadi dengan Debit Rencana 2 Tahun

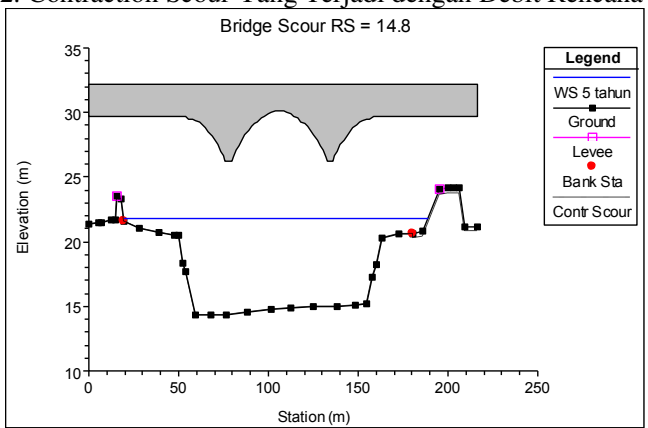

Gambar 3. Contraction Scour Yang Terjadi dengan Debit Rencana 5 Tahun.

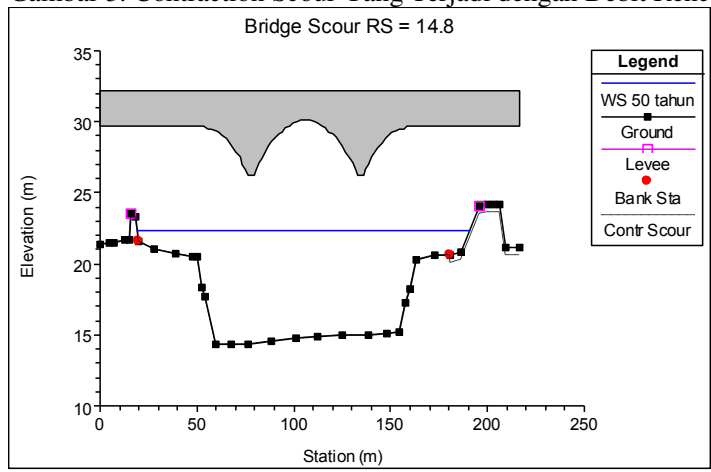

Gambar 6. Contraction Scour Yang Terjadi dengan Debit Rencana 50 Tahun

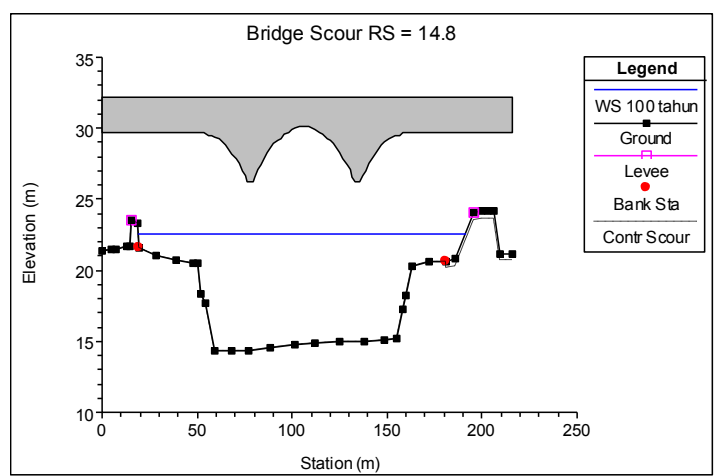

Gambar 7. Contraction Scour Yang Terjadi dengan Debit Rencana 100 Tahun

\begin{tabular}{rcccc}
\hline 25 tahun & $1.790,53$ & 0 & 0 & 0,37 \\
50 tahun & 1.93383 & 0 & 0 & 0,43 \\
100 tahun & $2.076,07$ & 0 & 0 & 0,47 \\
\hline \hline
\end{tabular}

\section{Permodelan Kondisi Sesudah Ada Jembatan}

Permodelan sesudah ada jembatan dimaksudkan untuk mengetahui prediksi kedalaman gerusan total akibat contraction scour dan pilar. Bentuk pilar adalah circular cylinder, data yang diisi adalah sudut datang dan ukuran sedimen d95.

Kondisi pilar jembatan dari gambar desain masih berada di atas dasar sungai, sedangkan bagian bawahnya yang berupa 
pile cap berada di bawah dasar sungai, sehingga dapat diketahui bahwa scouring yang akan terjadi adalah pada bagian pile cap tersebut. Namun pada tugas akhir ini disimulasikan pilar jembatan selebar 5,5 m tanpa adanya pile cap, ada pun alasannya adalah karena lebar pile cap yang sangat besar, yaitu $20 \mathrm{~m}$, sehingga hasil scouring yang akan terjadi dapat diprediksikan tidak rasional.

Berikut Gambar 8, Gambar 9, Gambar 10, Gambar 11, Gambar 12, dan Gambar 13 menunjukkan hasil simulasi untuk gerusan akibat contraction scouring dan pilar jembatn pada program Hec-Ras 5.0.3:

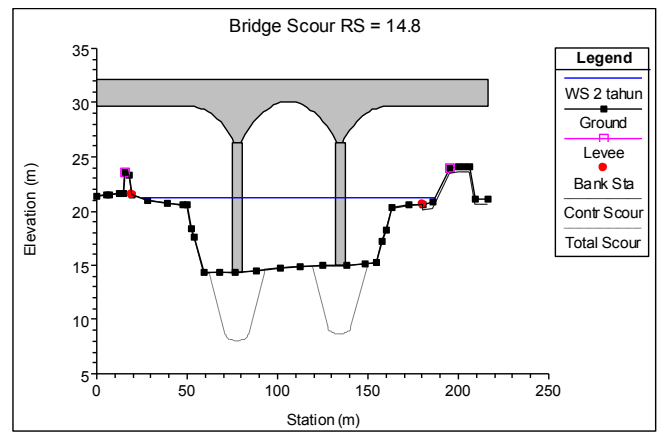

Gambar 8. Total Scouring Yang Terjadi dengan Debit Rencana 2 Tahun

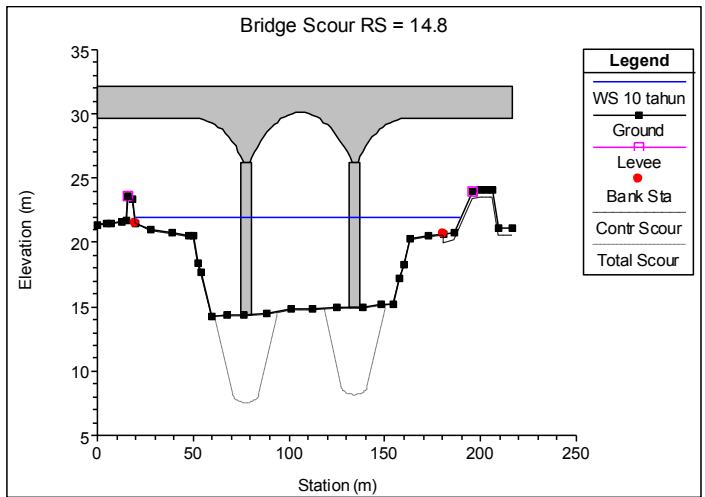

Gambar 10. Total Scouring Yang Terjadi dengan Debit Rencana 10 Tahun

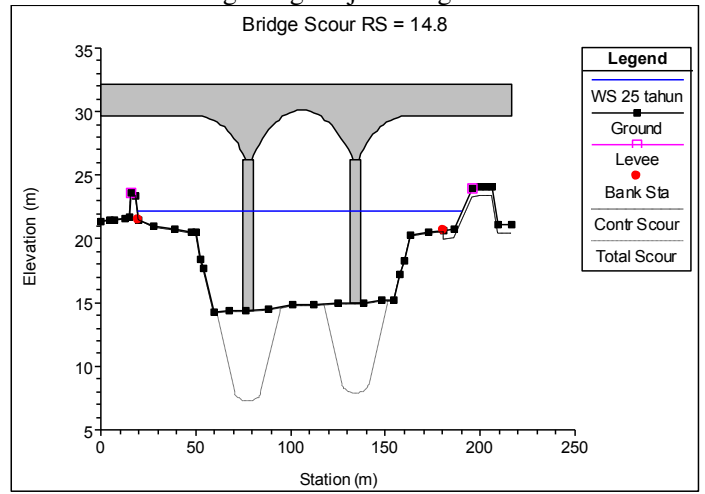

Gambar 11. Total Scouring Yang Terjadi dengan Debit Rencana 25 Tahun

Hasil analisa kedalaman total scouring disajikan dalam Tabel 4 di bawah ini.

Tabel 4.

Kedalaman Total Scouring terhadap Debit Periode Ulang

Scouring

\begin{tabular}{|c|c|c|c|c|}
\hline \multirow{2}{*}{ Periode Ulang } & \multirow{2}{*}{ Debit $\left(\mathrm{m}^{3} / \mathrm{dt}\right)$} & \multicolumn{3}{|c|}{ Scourlng } \\
\hline & & Contraction $(\mathrm{m})$ & $\operatorname{Pier}(\mathrm{m})$ & Total (m) \\
\hline 2 tahun & $1.213,58$ & 0,06 & 6,28 & 6,34 \\
\hline 5 tahun & $1.444,48$ & 0,09 & 6,53 & 6,62 \\
\hline
\end{tabular}

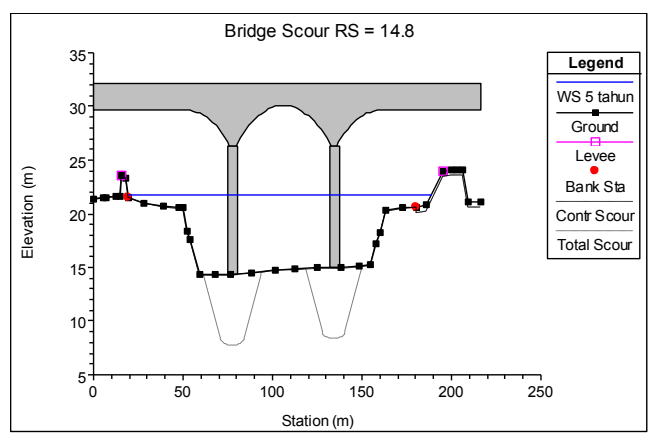

Gambar 9. Total Scouring Yang Terjadi dengan Debit Rencana 5 Tahun

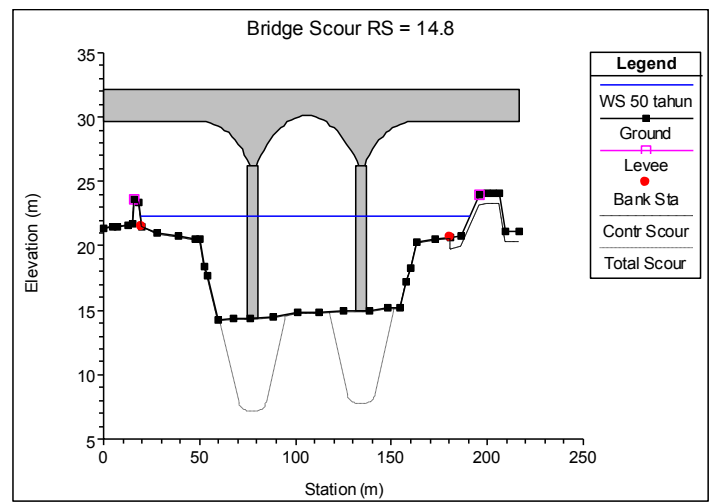

Gambar 12. Scouring Yang Terjadi dengan Debit Rencana 50 Tahun

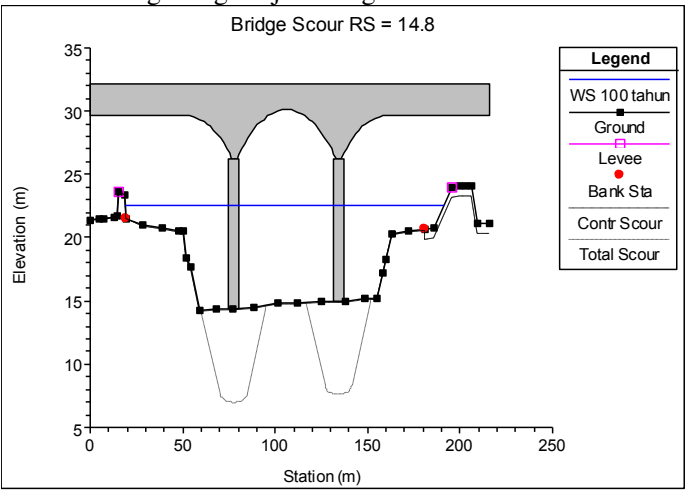

Gambar 13. Scouring Yang Terjadi dengan Debit Rencana 100 Tahun

\begin{tabular}{ccccc}
10 tahun & $1.597,36$ & 0,1 & 6,74 & 6,84 \\
25 tahun & $1.790,53$ & 0,11 & 6,97 & 7,08 \\
50 tahun & $1.933,83$ & 0,11 & 7,14 & 7,25 \\
100 tahun & $2.076,07$ & 0,11 & 7,29 & 7,4 \\
\hline
\end{tabular}

Sumber: Program Hec-Ras 5.0.3

4. Analisa Angkutan Sedimen antara Dua Penampang Sungai

Analisa angkutan sedimen antara dua penampang dilakukan dengan menggunakan rumus yang diusulkan oleh Neill (1973) untuk mengetahui gerusan antara dua pilar [2]. 
Caranya adalah dengan menentukan batas kecepatan tidak tergerus (non-eroding velocity), yaitu batas kecepatan di mana butiran sedimen tidak bergerak. Dalam perhitungan ini, kecepatan rata-rata yang dihasilkan oleh debit maksimum diasumsikan tidak menghasilkan adanya gerusan. Setelah itu, besarnya Ucompetent atau batas kecepatan tidak tergerus dapat ditentukan dari Gambar 2.12 pada BAB II dengan menggunakan kedalaman air di penampang dan ukuran butir sedimen.

Debit maksimum yang digunakan dalam analisa ini adalah debit periode ulang 100 tahun, yaitu $2.076,07 \mathrm{~m}^{3} / \mathrm{dt}$ dengan butir sedimen d50 rata-rata berdiameter $0,129 \mathrm{~mm}$. Gerusan akan terjadi apabila Urata-rata lebih besar daripada Ucompetent.

Hasil perhitungan yang ditampilkan pada Tabel 5 di bawah, kolom jarak menyatakan jarak penampang dari hilir lokasi studi dan sta 0 menunjukkan titik tinjau hilir. Selain itu, dapat diketahui bahwa sebagian besar penampang mengalami gerusan, salah satunya adalah sta 14,8 yang merupakan penampang jembatan Tol Mojokerto-Kertosono. Hasil analisa ini dapat dijadikan dasar untuk analisa angkutan sedimen.

Tabel 5.

Hasil Analisa Angkutan Sedimen dengan Debit 100 tahun

\begin{tabular}{|c|c|c|c|c|c|}
\hline $\begin{array}{c}\text { Jarak } \\
(\mathrm{m})\end{array}$ & $\begin{array}{c}\text { River } \\
\text { Sta }\end{array}$ & $\begin{array}{l}\text { Max Chnl } \\
\text { Depth (m) }\end{array}$ & $\begin{array}{c}\text { Vel Chnl } \\
(\mathrm{m} / \mathrm{s})\end{array}$ & $\begin{array}{c}\text { Competent } \\
\text { Vel }(\mathrm{m} / \mathrm{s})\end{array}$ & Ket. \\
\hline $1.634,31$ & 48 & 8,94 & 1,73 & 1,7 & scouring \\
\hline $1.583,7$ & 47 & 8,96 & 1,68 & 1,7 & no scouring \\
\hline $1.533,62$ & 46 & 9,55 & 1,75 & 1,8 & no scouring \\
\hline $1.482,74$ & 45 & 9,04 & 1,75 & 1,7 & scouring \\
\hline $1.432,63$ & 44 & 10,36 & 1,75 & 1,8 & no scouring \\
\hline $1.390,81$ & 43 & 10,71 & 1,68 & 1,8 & no scouring \\
\hline $1.347,23$ & 42 & 10,13 & 1,67 & 1,8 & no scouring \\
\hline $1.304,97$ & 41 & 10,16 & 1,57 & 1,8 & no scouring \\
\hline $1.257,29$ & 40 & 10,71 & 1,47 & 1,8 & no scouring \\
\hline $1.209,66$ & 39 & 10,43 & 1,41 & 1,8 & no scouring \\
\hline $1.151,98$ & 38 & 10,16 & 1,33 & 1,8 & no scouring \\
\hline $1.100,19$ & 37 & 9,55 & 1,47 & 1,7 & no scouring \\
\hline $1.046,99$ & 36 & 9,64 & 1,53 & 1,7 & no scouring \\
\hline 996,45 & 35 & 9,41 & 1,61 & 1,7 & no scouring \\
\hline 947,57 & 34 & 9,32 & 1,67 & 1,7 & no scouring \\
\hline 898,24 & 33 & 9,06 & 1,78 & 1,7 & scouring \\
\hline 872,91 & 32 & 10,91 & 1,63 & 1,8 & no scouring \\
\hline 845,57 & 31 & 9,52 & 1,77 & 1,8 & no scouring \\
\hline 823,58 & 30 & 8,99 & 1,82 & 1,7 & scouring \\
\hline 803,13 & 29 & 9,05 & 1,92 & 1,7 & scouring \\
\hline 781,31 & 28 & 9,59 & 1,85 & 1,8 & scouring \\
\hline 760,09 & 27 & 9,75 & 1,78 & 1,8 & no scouring \\
\hline 737,98 & 26 & 8,58 & 1,88 & 1,7 & scouring \\
\hline 716,12 & 25 & 8,69 & 1,91 & 1,7 & scouring \\
\hline 697,57 & 24 & 8,37 & 1,96 & 1,7 & scouring \\
\hline 679 & 23 & 8,3 & 1,9 & 1,7 & scouring \\
\hline 660,06 & 22 & 8,72 & 1,91 & 1,7 & scouring \\
\hline 639,16 & 21 & 8,64 & 1,94 & 1,7 & scouring \\
\hline 619,22 & 20 & 8,56 & 1,95 & 1,7 & scouring \\
\hline
\end{tabular}

Tabel 5 (lanjutan)

\begin{tabular}{cccccc}
\hline $\begin{array}{c}\text { Jarak } \\
(\mathrm{m})\end{array}$ & River Sta & $\begin{array}{c}\text { Max Chnl } \\
\text { Depth }(\mathrm{m})\end{array}$ & $\begin{array}{c}\text { Vel Chnl Competent Vel } \\
(\mathrm{m} / \mathrm{s})\end{array}$ & $\begin{array}{c}\text { Ket. } \\
(\mathrm{m} / \mathrm{s})\end{array}$ & scouring \\
\hline 596,7 & 19 & 8,56 & 2,1 & 1,7 & scouring \\
576,58 & 18 & 8,6 & 2,09 & 1,7 & scouring \\
555,71 & 17 & 8,4 & 2,08 & 1,7 & scouring \\
535,33 & 16 & 8,25 & 2,4 & 1,7 & scouring \\
515,94 & 15 & 8,29 & 2,21 & 1,7 & scouring \\
522,09 & 14,8 & 8,21 & 2,47 & 1,7 & scouring \\
493,1 & 14 & 8,37 & 2 & 1,7 & scouring \\
469,96 & 13 & 8,37 & 1,94 & 1,7 & scouring \\
486,66 & 12,3 & 8,33 & 2,07 & 1,7 & \\
\hline
\end{tabular}

\begin{tabular}{cccccl}
\hline 444,54 & 12 & 9,45 & 1,9 & 1,8 & scouring \\
419,14 & 11 & 8,15 & 2 & 1,7 & scouring \\
393,03 & 10 & 8,77 & 2,04 & 1,7 & scouring \\
367,9 & 9 & 8,14 & 2,05 & 1,7 & scouring \\
343,42 & 8 & 8,08 & 2,01 & 1,7 & scouring \\
319 & 7 & 8,61 & 1,92 & 1,7 & scouring \\
285,4 & 6 & 7,8 & 1,94 & 1,6 & scouring \\
253,3 & 5 & 7,67 & 1,92 & 1,6 & scouring \\
202,27 & 4 & 7,96 & 1,78 & 1,6 & scouring \\
149 & 3 & 7,72 & 1,86 & 1,6 & scouring \\
102 & 2 & 7,28 & 1,95 & 1,6 & scouring \\
57 & 1 & 6,48 & 2,32 & 1,5 & scouring \\
0 & 0 & 4,21 & 3,36 & 1,3 & scouring \\
\hline \hline
\end{tabular}

Sumber: Hasil Perhitungan

\section{Perhitungan Analitik Gerusan pada Pilar}

Perhitungan gerusan atau scouring secara analitik [3] dilakukan dengan menggunakan beberapa rumus, yaitu Garde \& Raju, Lacey, dan Neil (1964). Berikut adalah salah satu perhitungan scouring dengan debit periode ulang 2 tahun.

Diketahui:

$\begin{array}{ll}\text { Gs } & : 2,59 \mathrm{t} / \mathrm{m}^{3} \\ \text { D50 } & : 0,129 \mathrm{~mm} \\ \text { a } & : 5,5 \mathrm{~m} \\ \text { Q2 } & : 1.213,578 \mathrm{~m} 3 \\ \text { V2 } & : 1,18 \mathrm{~m} / \mathrm{s} \\ \text { d } & : 7,66 \mathrm{~m}\end{array}$

1. Garde dan Raju

$$
\begin{aligned}
& D=\left[\frac{4}{\alpha} \eta_{1} \eta_{2} \eta_{3} \eta_{4}\left(\frac{U}{\sqrt{g y}}\right)^{n^{*}}\right] y \\
& D \\
& =\left[\frac{4}{0,965} \cdot 0,684 \cdot 2,45 \cdot 0,5 \cdot 0,83 \cdot\left(\frac{1,18}{\sqrt{9,81 \times 7,66}}\right)^{0,74}\right] \cdot 7,66 \\
& \mathrm{D}=5,29 \mathrm{~m}
\end{aligned}
$$

2. Lacey

$$
\begin{aligned}
& d=0,473 \times\left(\frac{Q}{f}\right)^{0,33} \\
& d=0,473 \times\left(\frac{1.213,578}{1,76 \times \sqrt{0,129}}\right)^{0,33}=5,73 \mathrm{~m}
\end{aligned}
$$

3. Neill (1964)

$$
\begin{aligned}
& \frac{y_{s}}{y_{0}}=1,5\left(\frac{b}{y_{0}}\right)^{0.7} \\
& \frac{y_{s}}{7,66}=1,5\left(\frac{5,5}{7,66}\right)^{0.7} \\
& y_{s}=9,11 \mathrm{~m}
\end{aligned}
$$

Berikut Tabel 6 adalah hasil perhitungan untuk debit rencana lainnya.

Tabel 6.

Perhitungan Gerusan dengan Analitik

\begin{tabular}{ccccccc}
\hline \hline $\begin{array}{c}\text { Periode } \\
\text { Ulang }\end{array}$ & $\begin{array}{c}\text { Debit } \\
(\mathrm{m} 3 / \mathrm{dt})\end{array}$ & $\begin{array}{c}\text { Kecepatan } \\
(\mathrm{m} / \mathrm{s})\end{array}$ & $\begin{array}{c}\text { Garde \& } \\
\text { Raju }\end{array}$ & Lacey & Neil & $\begin{array}{c}\text { Rata- } \\
\text { rata }\end{array}$ \\
\hline 2 & $1.213,58$ & 1,18 & 5,29 & 5,73 & 9,11 & 6,71 \\
5 & $1.444,48$ & 1,29 & 6 & 6,07 & 9,28 & 7,12 \\
10 & $1.597,36$ & 1,34 & 6,38 & 6,27 & 9,39 & 7,35 \\
20 & $1.744,01$ & 1,40 & 6,8 & 6,46 & 9,47 & 7,58 \\
\hline
\end{tabular}




\begin{tabular}{ccccccc}
\hline 50 & $1.933,82$ & 1,48 & 7,33 & 6,68 & 9,57 & 7,87 \\
100 & $2.076,07$ & 1,53 & 7,7 & 6,84 & 9,65 & 8,07 \\
\hline \hline
\end{tabular}

\section{Analisa Angkutan Sedimen}

1. Permodelan Angkutan Sedimen pada Hec-Ras

Permodelan angkutan sedimen yang dilakukan dalam tugas akhir ini menggunakan pilihan analisa aliran tak permanen-semu atau quasi-unsteady flow yang terdapat pada Hec-Ras 5.0.3. Data-data yang akan dianalisa dimasukkan melalui opsi data editor pada Hec-Ras, yaitu quasi-unsteady flow editor dan dan sediment data editor.

Hasil analisa angkutan sedimen pada Hec-Ras 5.0.3 menunjukkan bahwa terjadi agradasi dan degradasi sedimen pada dasar sungai. Sebelum ada jembatan, degradasi terdalam yang terjadi adalah 5,97 meter dan agradasi setinggi 3,11 meter, dengan volume angkutan sedimen kumulatif adalah $386.551 \mathrm{~m} 3$ serta penurunan dasar sungai rata-rata sebesar $1,03 \mathrm{~m}$. Sedangkan setelah ada jembatan, degradasi yang terdalam adalah $6,00 \mathrm{~m}$ dan agradasi tertinggi adalah 2,97 $\mathrm{m}$, volume angkutan sedimen kumulatif yang terangkut adalah 569.775 m3 dengan penurunan dasar sungai rata-rata sebesar $1,51 \mathrm{~m}$.

Seperti hasil analisa angkutan sedimen untuk gerusan pada Tabel 5, dapat diketahui bahwa perubahan dasar sungai menunjukkan hal yang sama, yaitu terjadinya gerusan di sebagian besar penampang yang ditunjukkan oleh Gambar 14. Sedangkan perubahan dasar sungai untuk profil memanjang pada kondisi sebelum dan setelah adanya jembatan ditampilkan oleh Gambar 15 dan Gambar 16 di bawah ini.

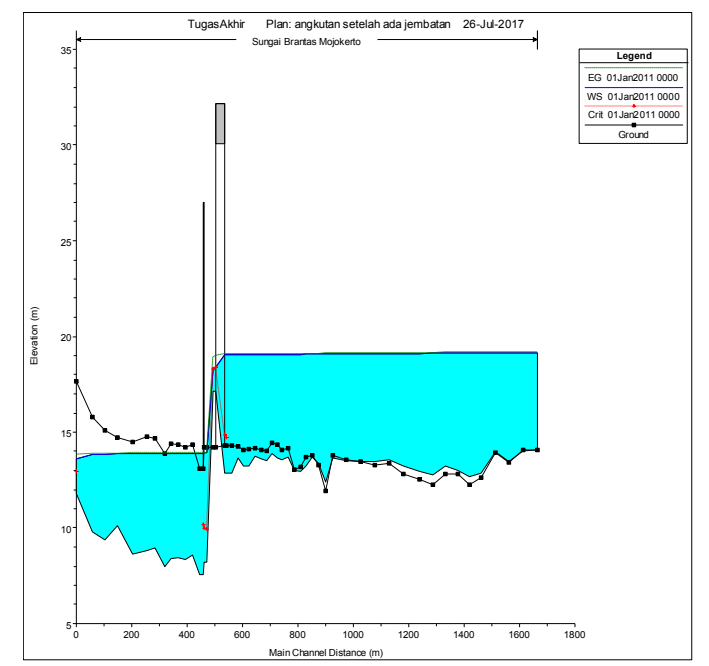

Gambar 14. Hasil Analisa Angkutan Sedimen pada Profil Memanjang

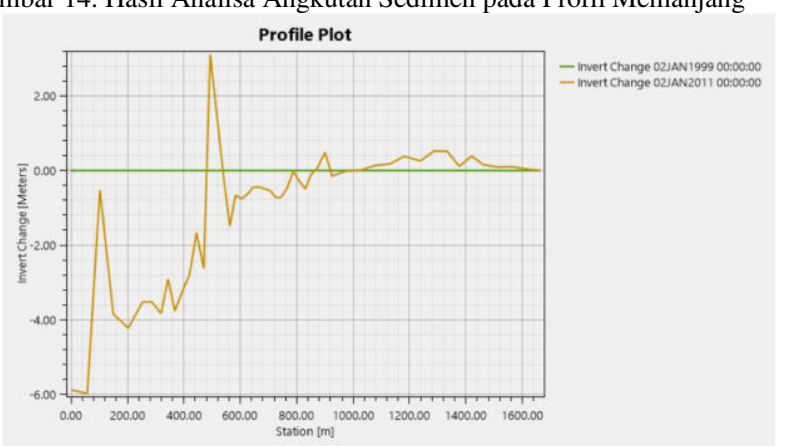

Gambar 15. Perubahan Dasar Sungai Sebelum Ada Jembatan

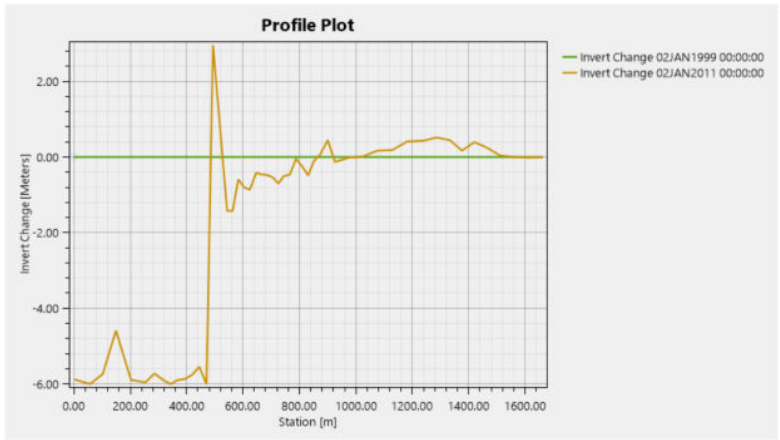

Gambar 16. Perubahan Dasar Sungai Setelah Ada Jembatan

\section{E. Perhitungan Analitik Angkutan Sedimen}

Konsentrasi angkutan sedimen dasar dihitung menggunakan rumus Laursen [4]. Debit air yang digunakan adalah debit air bulanan rata-rata dari data yang tersedia, sedangkan kedalaman yang digunakan dari analisa Hec-Ras. Berikut adalah contoh perhitungan untuk penampang A29 yang berada di sta 48 .

Diketahui:

D50: $0,129 \mathrm{~mm}$
$\mathrm{~S}: 0,002$
Suhu $\quad: 25^{\circ} \mathrm{C}$
$B \quad: 89 \mathrm{~m}$
Q $: 576,8 \mathrm{~m}^{3} / \mathrm{dt}$
$\gamma \mathrm{s}: 2,59 \mathrm{t} / \mathrm{m}^{3}$
$\gamma \quad: 1 \mathrm{t} / \mathrm{m}^{3}$
$\mathrm{~g} \quad: 9,81 \mathrm{~m} / \mathrm{s}^{2}$

Langkah perhitungannya adalah sebagai berikut:

Hal yang perlu diperhatikan adalah perhitungan analitis ini menggunakan satuan US Customary.

Kecepatan jatuh diperoleh dari grafik hubungan diameter butiran dengan kecepatan jatuh. Untuk diameter $0,129 \mathrm{~mm}$, suhu air 25C, dan shape factor diasumsikan 0,7 karena pasir alami maka diperoleh kecepatan jatuh $=\omega=27 \mathrm{~cm} / \mathrm{s}=0,27$ $\mathrm{m} / \mathrm{s}=0,886 \mathrm{ft} / \mathrm{s}$.

Kedalaman rata-rata penampang diperoleh dari trial dan eror sehingga diperoleh nilai koefisien Manning sesuai dengan data yaitu 0,03 . Koefisein manning tersebut dihitung dengan persamaan

Di mana

$$
n=\frac{R^{2 / 3} \cdot S^{1 / 2}}{V}
$$

$$
R=\frac{A}{P}=\frac{(b+m h) h}{b \quad 2 h \overline{m^{2} 1}}
$$

dicoba nilai kedalaman rata-rata $=\mathrm{D}=\mathrm{h}=3,075 \mathrm{~m}=$ $10,088 \mathrm{ft}$

Luas penampang basah $A=(b+m h) h$ $=3047,264$

Keliling bash $P=b+2 h \sqrt{m^{2}+1}=320,527$

Jari-jari hidrolis, $\mathrm{R}=9,507$

Kecepatan rata- $\mathrm{ft} / \mathrm{s}, \mathrm{V}=6,681 \mathrm{ft} / \mathrm{s}$

Keofisien Manning $=0,03(\mathrm{OK})$

Kecepatan geser $\mathrm{U} *=\sqrt{g . D . S}$

$=\sqrt{9,81} \times 3,075 \times 0,002=0,806 \mathrm{ft} / \mathrm{s}$

Angka Reynold, $\operatorname{Re}=31,684$

Tegangan geser $\tau^{\prime}=\frac{\rho V^{2}}{58}\left(\frac{d_{50}}{D}\right)^{1 / 3}=1,669 \mathrm{lb} / \mathrm{ft} 2$

Tegangan geser kritis diperoleh dari diagram Shield dengan berdasarkan pada besar angka Reynold. Dari grafik tersebut terlebih dahulu didapatkan nilai dimensionless 
shear stress $\left(\tau_{*}\right)$, sehingga tegangan geser kritis dapat dihitung.

Untuk $\mathrm{Re}=31,684$ diperoleh besar $\tau_{*}=0.035$, maka tegangan geser kritis $\tau_{c}=\tau_{*}\left(\gamma_{\mathrm{s}}-\gamma\right) \cdot \mathrm{d}_{50}$

$$
=0,00147
$$

Konsentrasi sedimen

$\mathrm{C}_{\mathrm{t}}=1.067 \mathrm{ppm}$

Debit muatan sedimen per satuan lebar penampang

$q s=q \times C t=0,494 \times 2,217=1,096 \mathrm{~kg} / \mathrm{s} / \mathrm{m}$

Debit muatan sedimen

$$
Q s=q s \times B=1,096 \times 145=158,85 \mathrm{~kg} / \mathrm{s}
$$

Hasil perhitungan analitik ini kemudian dibandingkan dengan hasil yang didapatkan pada simulasi sedimen di Hec-Ras, dan menunjukkan hasil yang saling berdekatan, seperti yang dapat dilihat pada Tabel 7 dan Gambar 17.

Tabel 7.

Perbandingan konsentrasi sedimen simulasi Hec-Ras dan Analitik

\begin{tabular}{ccc}
\hline \hline Tahun & Hec Ras & Analitik \\
\hline 1999 & 868,29 & 988,48 \\
2000 & 859,72 & 972,00 \\
2001 & 808,58 & $1.031,96$ \\
2002 & $1.170,17$ & 909,53 \\
2003 & $1.155,70$ & $1.083,19$ \\
2004 & $1.211,98$ & $1.132,91$ \\
2005 & $1.281,38$ & $1.170,43$ \\
2006 & $1.272,59$ & $1.167,79$ \\
2007 & $1.473,36$ & $1.165,6$ \\
2008 & $1.383,83$ & $1.137,51$ \\
2009 & $1.383,29$ & $1.162,43$ \\
2010 & $2.391,99$ & $1.073,44$ \\
\hline \hline
\end{tabular}

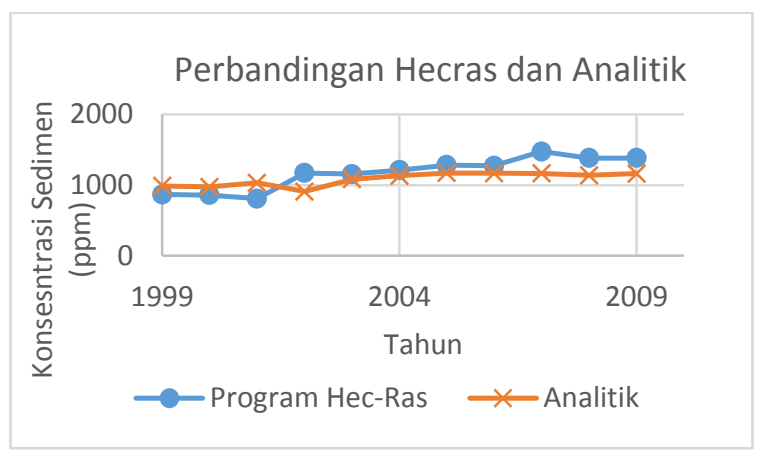

Gambar 17. Grafik Perbandingan Analisa Hec-ras dan Perhitungan Analitik

\section{KESIMPULAN}

Berdasarkan studi yang telah dilakukan, didapatkan kesimpulan sebagai berikut.

1. Besar debit aliran rencana di sungai Brantas untuk 2 tahun, 5 tahun, 10 tahun, 25 tahun, 50 tahun, dan 100 tahun secara berturut-turut adalah $1.213,58 \mathrm{~m}^{3} / \mathrm{dt}$, $1.444,48 \mathrm{~m}^{3} / \mathrm{dt}, \quad 1.597,36 \mathrm{~m}^{3} / \mathrm{dt}, \quad 1.790,53 \mathrm{~m}^{3} / \mathrm{dt}$, $1.933,83 \mathrm{~m}^{3} / \mathrm{dt}, 2.076,07 \mathrm{~m}^{3} / \mathrm{dt}$.

2. Hasil analisa angkutan sedimen pada Hec-Ras menunjukkan bahwa terjadi agradasi dan degradasi sedimen pada dasar sungai. Sebelum ada jembatan, degradasi terdalam yang terjadi adalah 5,97 meter dan agradasi setinggi 3,11 meter, dengan volume angkutan sedimen kumulatif adalah $386.551 \mathrm{~m}^{3}$ serta penurunan dasar sungai rata-rata sebesar $1,03 \mathrm{~m}$. Sedangkan setelah ada jembatan, degradasi yang terdalam adalah $6,00 \mathrm{~m}$ dan agradasi tertinggi adalah $2,97 \mathrm{~m}$, volume angkutan sedimen kumulatif yang terangkut adalah $569.775 \mathrm{~m}^{3}$ dengan penurunan dasar sungai rata-rata sebesar $1,51 \mathrm{~m}$.

3. Berdasarkan hasil permodelan, dapat diketahui jika keberadaan jembatan memberikan pengaruh terhadap angkutan sedimen di penampang sungai disekitarnya. Pada tugas akhir ini, adanya jembatan tol MojokertoKertosono memberikan pengaruh pada angkutan sedimen.

4. Dari analisa pada permodelan Hec-Ras, dapat diketahui bahwa pilar jembatan menyebabkan terjadinya gerusan lokal. Kedalaman gerusan yang terjadi pada debit rencana 100 tahun adalah $7,4 \mathrm{~m}$ yang mendekati hasil perhitungan analitik dengan kedalaman rata-rata didapat $8,07 \mathrm{~m}$.

\section{DAFTAR PUSTAKA}

[1] G. W. Bruner, HEC-RAS 5.0 Reference Manual. Davis: US Army Corps of Engineers, 2016.

[2] E. L. Pemberton and J. M. Lara, "Computing Degradation and Local Scour," Colorado, 1984.

[3] H. N. . Breusers and A. J. Raudkivi, Scouring. Netherlands: A.A Balkema Publishers, 1991.

[4] C. T. Yang, Sediment Transport: Theory and Practice. Singapore: Mc Graw Hill, 1996 